Review

\title{
INFECTIOUS PANCREATIC NECROSIS OF SALMONID FISH - DISTRIBUTION AND LABORATORY METHODS FOR DIAGNOSIS
}

\author{
E. Mileva* \\ NRL of Fish, Mollusc and Crustacean Diseases, National Diagnostic Research Veterinary \\ Institute, \\ Sofia, Bulgaria
}

\begin{abstract}
One of the fastest growing branches of the national livestock breeding in Bulgaria is aquaculture production. The development of aquaculture production is directly related to the health of the cultivated fish and indirectly to the health of the wild fauna. Economically, breeding can be severely complicated by the appearance of infections especially those ones with viral etiology. The most serious problem for Bulgarian trout producers over the last decade is Infectious pancreatic necrosis (IPN) which is a highly contagious viral disease of young salmonid fish. It is caused by a virus (IPNV) that belongs to the family Birnaviridae. The IPNV has been isolated from many geographic regions around the world with different environments and a variety of aquatic animals. In Bulgaria, the IPNV was confirmed 13 years ago. There are several cases with heavy mortality rates every year. Thus, the aim of this review was to extend knowledge of IPN, and to present methods of its control.
\end{abstract}

Key words: Infectious pancreatic necrosis, Aquabirnavirus, salmonid fish, control

\section{INTRODUCTION}

One of the fastest growing branches of the national livestock breeding in Bulgaria is aquaculture production (1). Our country is relatively rich in natural freshwater resources suitable for the rearing of warm and cold water fish species (2). The most preferable cold water species are salmonids such as Brown trout (Salmo trutta) and perfectly adapted to our conditions Rainbow trout (Oncorhynchus mykiss). Another salmonid that was successful introduced is Brook trout (Salvelinus fontinalis). In the recent years, several closed recirculating systems have been created to grow Atlantic salmon (Salmo salar) and Coho salmon (Coho salmon).

For the first time, the disease is described as catarrhal enteritis due to a poor nutrition of young trout up to $10 \mathrm{~g}$ (16). Later on, the clinical signs were described by Wood in 1955 for North American cases (38), but these

\footnotetext{
*Correspondence to: Ekaterina Mileva, NRL of Fish, Mollusc and Crustacean Diseases, National Diagnostic Research Veterinary Institute, Sofia, Bulgaria, 1606 Blvd. №15 "Pencho Slavejkov", +359878246454; katrin_r@abv.bg
}

clinical signs were already noted in the United States in 1920 (39). In Europe, it was reported to have occurred in the 1960s in France (9) and shortly after that, there were notes about it from different European countries. There are 649 registered fish farms in Bulgaria. 105 of them, breed and cultivated salmonids approximately $16 \%$. The districts with significantly more salmonid farms than others are Smolyan, Blagoevgrad, Sofia and Pazardzik - more than $87 \%$ of all (106).

The development of aquaculture production is directly related to the health of the cultivated fish and indirectly to the health of the wild fauna. Economically, breeding can be severely complicated by the appearance of infections especially those ones with viral etiology which lead to global losses of around $20 \%$ of production (4). To present, there are over 100 viruses that are pathogenic to fish. They belong to 14 families: Herpesviridae, Iridoviridae, Adenoviridae, Birnaviridae, Rhabdoviridae, Paramyxoviridae, Coronaviridae, Picornaviridae, Retroviridae, 
Reoviridae and others (5). Under Directive 88/2006/EC (93) and Decision 1554/2015/EC (87) as implemented in Bulgaria by Regulation 17/2008 mandatory testing is necessary only for viral diseases ("listed diseases" compulsory subject when an outbreak of infection appears). They cause the greatest and destructive damage, the most difficult to manage, and treatment with known chemotherapeutics is not possible.

The most serious problem for Bulgarian trout producers over the last decade is the infectious pancreatic necrosis (IPN) (3).

The aim of this paper is to summarize and present the information about the distribution, prevention, and control of IPN and the nature of causative agent IPNV. Retrospective view at available data from first reports to present should indicate why the main problem in our salmonid aquaculture farming is precisely IPNV.

\section{DISTRIBUTION}

In the IPNV survey of 2017, Rimstad (6) stated that the virus was widespread all over the world:
The IPN occurred in Europe - the main producer of trout - in Belgium, areas of the former Czechoslovakia, Finland, Luxembourg, Spain, Serbia, Montenegro (7), Denmark (8), France (9), Germany (10), Italy (11), Norway (12), Sweden (13), and the United Kingdom (14). IPNV is present in most areas of North America - Canada (15, 7); United States (7). Central and South America the virus was isolated from Mexico (95), Chile (96). The authors reported occur from Asia - Japan (16) through China (17) to Turkey (18). Only one author points out IPNV is also present in Russia (97). In the southern hemisphere, IPN was reported in Australia (7), Tasmania (19), New Zealand (7, 20). South Africa (7) and ocean open waters: $(16,17,21-24)$.

From Bulgarian aquaculture farms the IPN virus was isolated for the first time in 2006 at the "Sini hancheta" farm, Smolyan District. Thereafter, it was isolated in 2007 while after 2009 the number of outbreaks increased (Figure 1). Eighteen outbreaks were registered to 2014 (1).

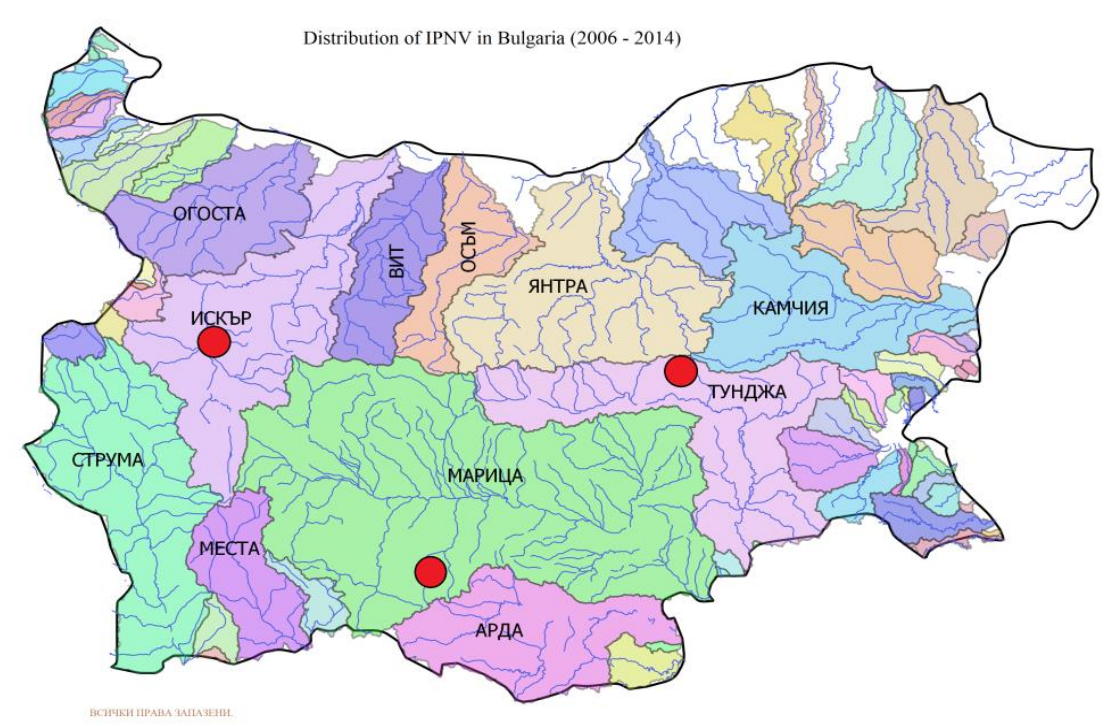

Figure 1. Distribution of IPNV in Bulgaria to 2014 by river catchments (personal data)

\section{ETIOLOGY}

- Classification

Birnaviridae family includes four genera with double-stranded RNA - Aquabirnavirus, Avibirnavirus, Blosnavirus, and Enthomobirnavirus (25). IPNV is the type species of genus Aquabirnavirus. Serologically and biochemically related viruses in this genus induce a variety of disease syndromes in taxonomically diverse host groups, which also include aquatic invertebrates (7).
- Morphology

The genus Aquabirnavirus includes icosahedral, double-stranded (ds), bi-segmented RNA viruses with a non-enveloped capsid. measuring $60 \mathrm{~nm}$ in diameter. Genome

segment A encodes all the structural (VP2 and VP3) and non-structural proteins whereas Segment B encodes the viral RNA-dependent RNA polymerase (VP1) (29). 
- Biological features

Based on the genome analysis of multiple strains of IPNV, two serogroups are distinguished: A - with 9 serotypes and B - with 1 serotype $(29,30)$. Initially, two strains - Ab and $\mathrm{Sp}$, which are different from each other and from strain VR299, were isolated in Denmark from the rainbow trout $(30,98)$.

At the present, IPN and IPN-like viruses are classified into the already mentioned serogroups A and B. All strains of A are pathogenic to fish (28). Serotype A1 covers most of North America-specific strains while A6 - A9 strains are mainly isolated in Canada. The four remaining types from A2 to A5 are isolated in Europe.

Serogroup B contains an non-pathogenic for fish TV-1 (Tellina virus) $(30,31)$.

- Genomic structure

The viral RNA contains two linear segments A and B. Segment A has a large ORF (open reading frame) that codes a $106 \mathrm{kDa}$ polyprotein (NH2-pVP2-VP4-VP3-COOH) and a small ORF that binds the amino terminus of the VP5 polyprotein size $17 \mathrm{kDa}$. This polyprotein is unstructured, anti-apoptotic (34) and in the assembling phase of the virus, it forms: pVP2 - the protein precursor VP2 (large capsid protein), VP4 (protease function), and VP3 (small capsid protein) forms complexes with genomic RNA in the capsid of the virus (34). Segment B codes VP1-RNA-dependent RNA polymerase, which is both free in the viral particles and covalently linked to the viral genome (35).

A phylogenetic sequence analysis based on amino acids of segment A (protein VP2) indicates that there are seven IPNV genotypes separated by geographic and serological characteristics. Differences between genotypes vary between $18-30 \%$ and show wide antigenic diversity $(28,32)$. The two serogroups, accepted in general, did not respond to a virusneutralization cross reaction but the author (30) described a serotype TV-1, pathogenic for bivalve mollusks of the genus Tellina (31), showing antigenic similarity to two strains of IPNV.

The virus may survive at a temperature of about $10^{\circ} \mathrm{C}$ for 7 months (89), several years at $-20^{\circ} \mathrm{C}$ (some strains are sensitive to freezing and thawing, especially if the environment they come into has low $\mathrm{pH}$ ). It is resistant to exposure to ether, chloroform and glycerol. It is inactivated by chlorine, iodophors and UV radiation.

\section{EPIZOOTOLOGY}

The disease affected predominantly young salmonids - the fried trout and Atlantic postsmolts (99). Clinical signs vary and include behavioral changes as spiral swimming, exophthalmos, open operculums bilaterally, anorexia (36).

Worldwide epizootic studies have shown that IPNV is actively circulating, surviving in a variety of conditions, and is isolated from a variety of vectors and sources - wildlife fish, clams (exploring sedimentary samples around Spain's fishing farms) and even food pellets even after (physicochemical) treatment (38).

From IPNV first isolation in the United States, it seemed that infections were limited to such salmonid fish (42). Then, the current theory that IPNV infects only salmonids has been revised when the virus was isolated from healthy white sucker - freshwater Cypriniform fish (Catostomus commersoni) (43) and from Japanese eel (Anguilla japonica) (98). The known hosts range to present includes fish from more than 30 families. Some important for our region non-salmonids are: Cyprinus carpio, Carassius aurata, Abramis brama, Esox lucius, Anguilla Anguilla, Barbus barbus, Astacus astacus, Danio rerio, Mytylus edulis, M. galloprovincialis, Hirudo medicinalis, etc. Most of them have been experimentally infected. Domesticated hosts except salmonids are Limanda limanda, Seriola quinqueradiata, Psetta maxima, and Hyppoglossus hyppoglossus (6).

The complete epizootic cycle of the virus has not yet been fully clarified. It is not possible to establish why viral antigen is detected in areas where there are no fish farms - rivers, lakes, dams or seawater with no possible vectors. According to Souter (39), detection of the virus in the internal organs of 229 samples of Arctic charr (Salvelinus alpinus) harvested at the beginning of the breeding season in various habitats - the delta and upstream of the Mackenzie River and the rivers on the Yukon territory, where there are almost no humans and no aquaculture.

The virus is transmitted horizontally and vertically. It is proven for salmonids but in nonsalmonids - farmed turbot or halibut which are susceptible, there is no enough research $(40,41$, 49). Vertical transmission is intraovarian - via infected eggs or seminal fluids (42).

The optimal temperature of virus replication varies and depends on the host and the strain. Juvenile brook trout (Salvelinus fontinalis) 
infected with North American strain had maximum mortality at $10^{\circ} \mathrm{C}$ but the challenge with VR 299 cause the similar mortality at $15.5^{\circ} \mathrm{C}(105)$

After an experimental infection, Molloy et al., demonstrated (2013) that Mytilus edulis has the ability to accumulate and transmit IPNV (99). Other researchers (102) observed viable virus in the digestive gland, muscle, gonads and rectum tissue at 333 day after the experimental injection of IPNV into the adductor muscle of scallop.

Swanson et al., after an experimental infection trial of IPNV using fry trout reported data about 2 days latent period after the inoculation in which the virus can be detected in the water. After these 2 days, there is a period of 2-4 days through which the fish manifest a clinical sign. This incubation time depends on the environmental and internal factors (101).

\section{DIAGNOSIS}

CLINICAL AND PATHOLOGICAL SIGNS

Diagnosis is based on clinical signs, laboratory examination, and case history.

Clinical signs can be seen only in small fish up to $10 \mathrm{~g}$, most often $0.1-3 \mathrm{~g}$ (43). Fish weighing approximately $50-100 \mathrm{~g}$, mortality at IPN is about $38-45 \%$. At this stage of development, there are physiological changes that cause both stress and decreased immunity $(45,46)$.

Predisposing factors for increasing the virulence of IPNV are age, stress and water temperature. External signs are non-specific, but can be used as a guide: blackening of the body (hyperpigmentation), exophthalmia, ascites (47) as shown in Figure 2:

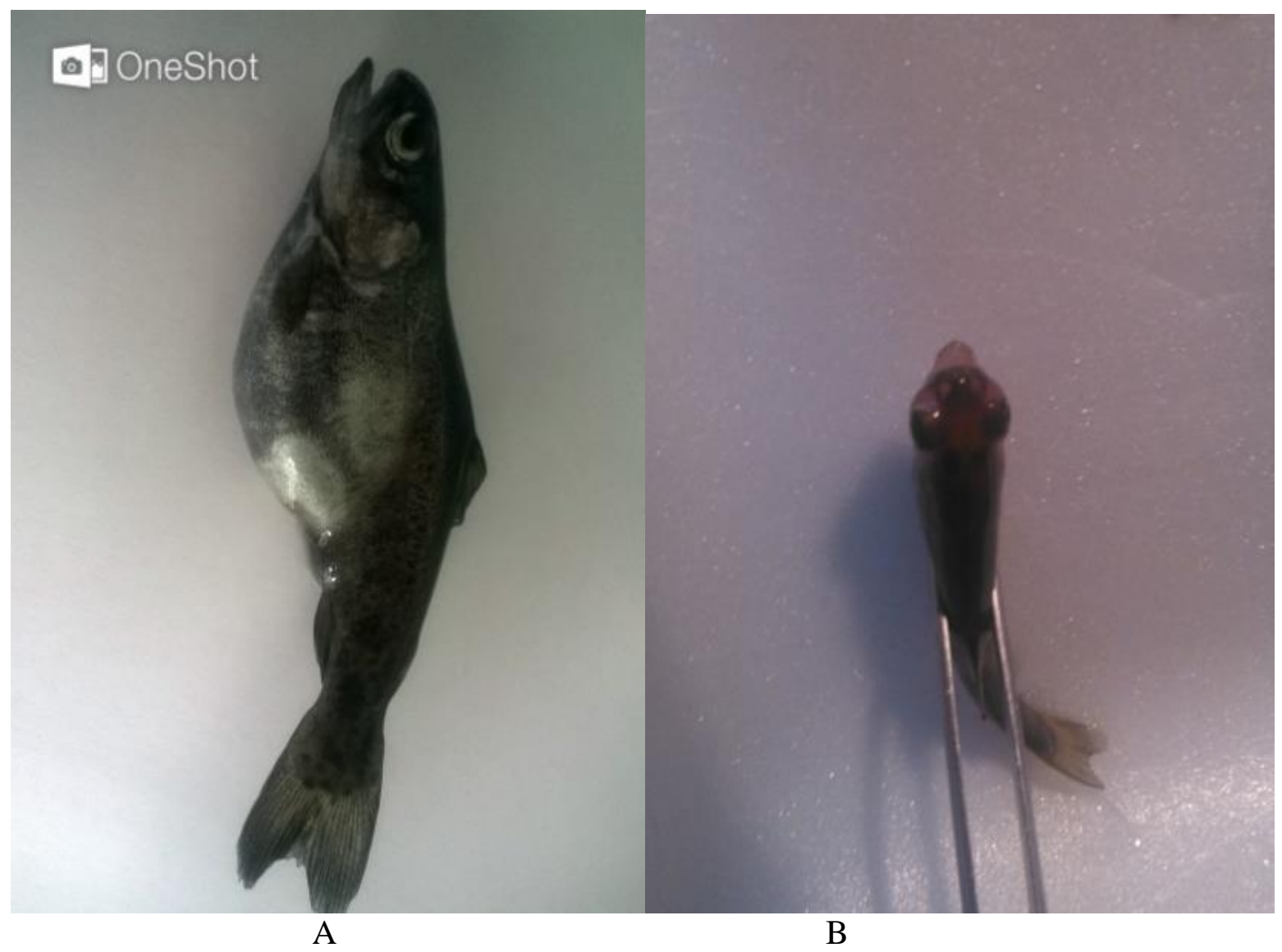

Figure 2. External signs of IPN: A-post mortem; B-in vivo (personal data).

Less common - lesions or petechiae, especially in the area of gills. The gills are anemic (47). The gross pathology of the infected young fish may include an empty stomach and intestinal tract. The pyloric caeca may have petechiae and the body cavity may contain milky exudate (Figure 3). This signs are presented in Figure 3: 


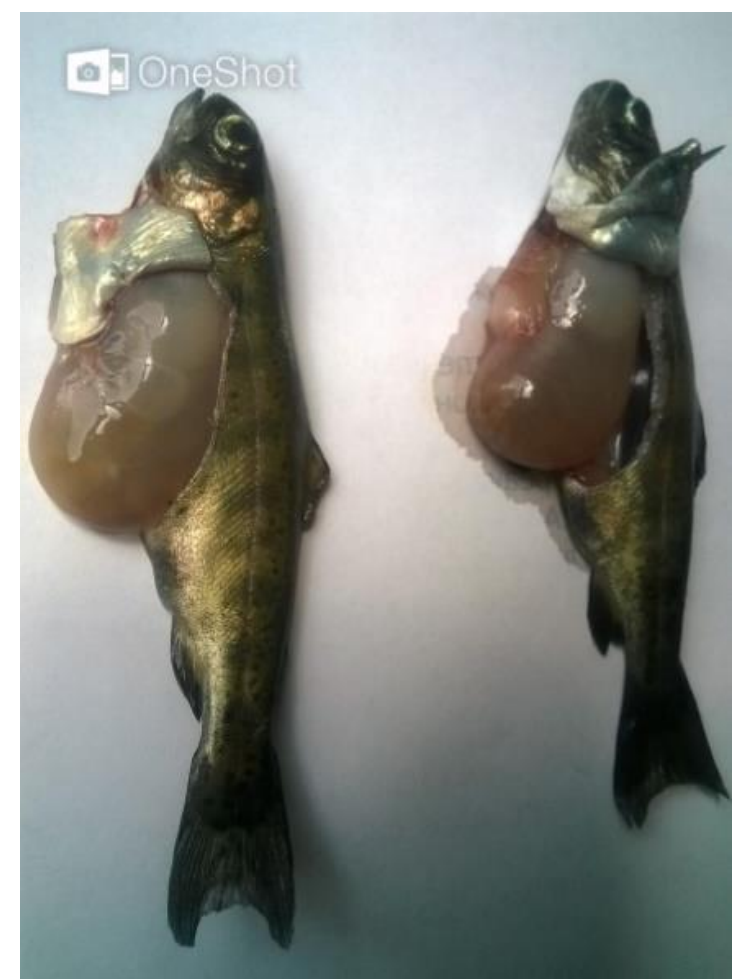

Figure 3. Gross anatomy pathology in situ of pyloric caeca with apical hemorrhage (personal data).

Anorexia, frequent pseudo-fecal portion and atypical swimming behavior can also help diagnosis. Movements are often uncoordinated periods of lethargy can be followed by fast and atypical swim (for example, rotating like a corkscrew). A clinic sign may be missing, but high mortality is an indication for a possible infection with IPNV $(36,37)$.

Some researchers have seen the same signs demonstrated by non-trout fish species infected with IPN-like viruses $(30,49,50,51)$. According to Evensen (52), in the acute phase of the infection mortality can reach $100 \%$. In young fish, it can be restricted by increasing immunity and modifying environmental factors (53).

Marine fish, infected with pathogenic aquarium viruses, can have clinical signs as abdominal ascites and /or spinal deformity or may have no clinical signs. Laboratory testing only shows the presence of viral antigen in tissues $(54,55)$.

No clinical signs have been reported so far in the presence of Tasmanian aquabirnavirus (TAB). Changes can only be seen in histological examination (19).

Fish from the elderly technology group may have the virus, but they do not show any clinic or pathoanatomical alterations. Even though they continue to release excretions containing IPNV, which is a potential cause of horizontal transmission of the infection (41). The titer of viral particles from the elderly survived fishes may vary from non-detectable to relatively high
(56). Occasionally, in the lamina propria cells of the asymptomatic Atlantic salmon - this cells socalled "McKnight cells" - necrotizing histiocytes can be seen (60).

Histopathological changes may include hemorrhage in the liver, swollen respiratory epithelium in gills, massive necrosis in acinar cells with vacuolar degeneration of pancreatic cells. The cells have a pyknotic nucleus and karyorrhexis (102). Since clinical signs are nonspecific and pathological changes are not certain, the final diagnosis depends on the selection of the exact virus detection method or viral antigen detection method. There are two possibilities. The first one is direct evidence in tissues that have responded to infection or tissue processing.

The pathoanamic finding is unclear. There may be lesions or haemorrhages in the apical part of the pyloric. Observed under a microscope, with immunohistochemical methods and by appropriate use of staining, you can see necroses in pancreatic cells (acini) and hematopoietic kidney cells (48).

Fish weighing over 10-12 g and older than 6 months are resistant to disease. The carriers are asymptomatic but periodically virus ejection with feces and gonads product maintenance the infection in susceptible fish $(103,104)$.

\section{LABORATORY METHODS}

The second is to cultivate a supernatant derived from them on an appropriate cell cultures and subsequent identification. 
One of the most accurate direct methods is the electron microscopy of tissue slides.

- Cultivation and serological methods

A standard for proving the presence of viral antigen in salmonids is object of regulatory and it's described in MDTAA (61). The sampling tissue from the correct organ (spleen, anterior kidney, heart, encephalon, ovarian or seminal fluids) and inoculation of obtained by grinding supernatant into cell cultures (Figure 4).

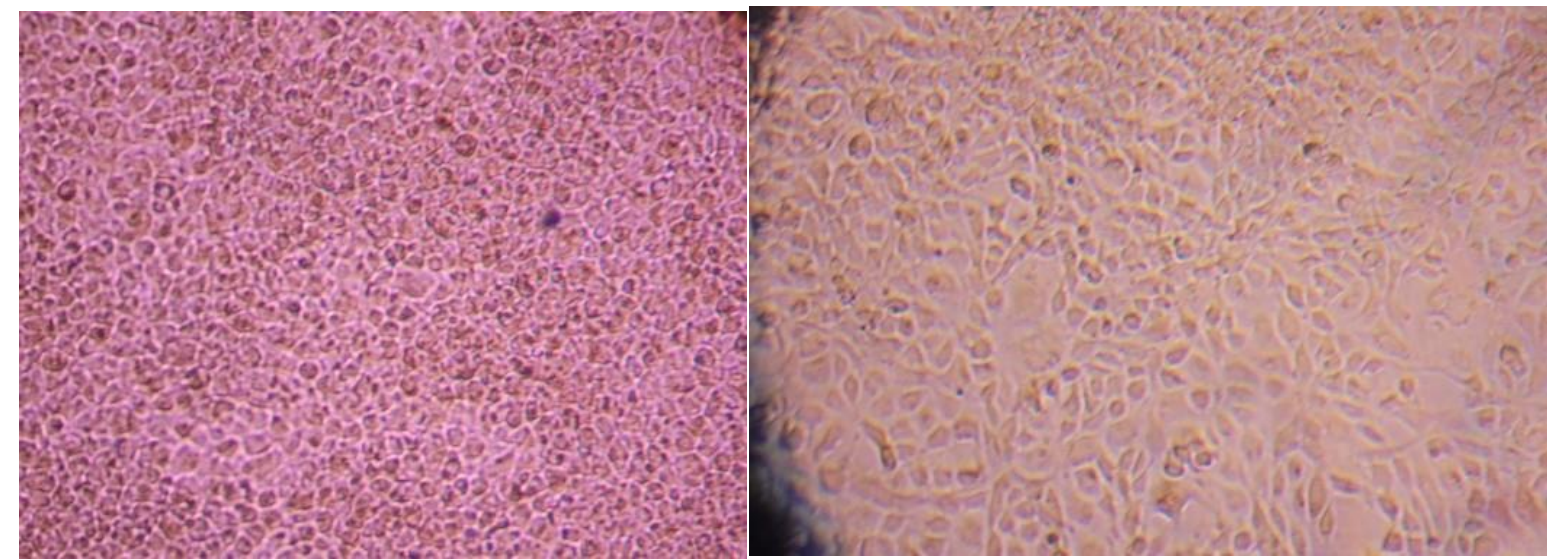

Figure 4. A-EPC - normal monolayer; B-CPE - after $48 \mathrm{~h}$ of inoculation with IPNV (personal data).

In case of small fry sampling is from whole fish or from the viscera including a kidney - its depend on body length (87). Different cell lines - CHSE-214, BF2, EPC, RTG-2, FHM are used (59-61). When there is a cytopathic effect (CPE) - Figure 8 methods that can confirm it are usually serological - ELISA, IFAT, VN, immunoperoxidase, flow cytometry, immunodot-blotting, immunostatic fibroblast protein A (62). These methods are sensitive, specific and fast and are suitable for routine diagnosis in the acute phase of the disease as well as suspected latent carriers but they require at least two weeks. They are confirmed as a standard for several reasons:

- the virus is confirmed $100 \%$, as it is in a relatively high titre in the precursor tissues - spleen; immunogenic part of the kidney, and brain; (63);

- - there is no latent phase during which IPNV cannot be isolated and cultivated;

- $\quad$ - the cell lines used are highly sensitive (60);

- - requires a prolonged period of time during which CPE may be initiated in several ways - titration, change of $\mathrm{CC}$, addition of enzymes, etc. (64-66);

- - ELISA is a suitable confirmatory method (67), as well as IFAT (68) - both methods have come into practice and can be combined with more advanced molecular methods if needed $(69,62)$.

\section{- Molecular methods}

The use of molecular methods as stand-alone or as confirmation of aquabirnaviruses, found via other methodologies, began in the early 1990s.
Protocols for virus confirmation are developed in the CC (70-74). Developments are made with the prevalence of amplification methods, but in 2004, Alonso et al. (75) developed an in situ hybridisation (ISH) method for detecting the virus in infected BF-2, EPC and CHSE-214 CC, which however was not widely used.

Reverse transcriptase polymerase chain reaction RT PCR and RT qPCR - real-time reaction is much more popular.

Various variants of RT PCR are now widely used to demonstrate IPNV. The first protocol was developed by Lopez-Lastra in 1994 (76). In 1995 (72) and 2001 (74) various modifications were developed to confirm isolates from cell cultures. Later, BarlicMaganja et al. (77) and Shivappa et al. (78) use their protocols to prove the virus. In a comparative study of 5 serological methods and conventional RT PCR (62), the authors demonstrated that the most sensitive and suitable for routine diagnosis methods of virus detection in tissues (in the acute phase of IPN development) are molecular. Protocols for nested RT PCR were developed $(79,80)$. Realtime reverse transcriptase polymerase chain reaction $(\mathrm{RTqPCR})$ was used for the first time successfully for fish viruses successfully by Dhar et al. (80). They used fluorescent staining with SYBR Green I. Thereafter, the use of the TaqMan probe was proved for different viral fish pathogens (82). The first RTqPCR-based screening based on the use of a probe is made by Orpetveit et al. (83) in Norway. According to the authors, the method is 100 times more sensitive than the conventional one but a major 
disadvantage of molecular methods is confirming the presence of a viral antigen regardless the virus is alive or not.

\section{DIFFERENTIAL DIAGNOSIS}

Many of the observed clinical signs in the acute phase of the infection such as open gills, exophthalm, darkening of the skin surface, ascites, enlarged spleen, chaotic movements are similar to those of other diseases - VHS, IHN, ISA $(84,85)$ mass infestations, myxosis, bacterial infections, especially in fish about $100 \mathrm{~g}$ (86).

The laboratory standard, including inoculation on a suitable cell line, identifies the virus only after a serological examination of the supernatant collected from the wells of the plaque with $\mathrm{CC}$. Since IPNV is believed to be worldwide spread, the OIE recommends adding antiserum to the inoculant supernatant in the $\mathrm{CC}$ in the screening of VHS and IHN. The purpose is to prevent CPE due to the presence of IPNV. RT PCR or RT qPCR is recommended as a parallel method for fast identification (87).

\section{CONTROL AND PREVENTION}

IPNV is extremely resistant to most disinfectants because of the vertical transmission. Its virulence decreases significantly when heated to $55-60^{\circ} \mathrm{C}$, ozone, formalin, drying, and extreme $\mathrm{pH}$ values below 2 and above 12 (89). This makes it especially dangerous for susceptible risk groups of fish in neighboring farms - located along the catchment area or just close to it. Transmission can also be carried out on the import of feed material, inventory, etc. (90).

To prevent the spread of IPN and to reduce damage, it is necessary to strictly comply with hygiene and regulatory requirements:

1. Control over the movement of the material, live fish and facilities in the country and in individual farms to be strict (91).

2. The import of fertilized caviar shall be carried out by disease-free farms. Caviar must have a certificate of origin from a disease-free farm or a negative result for virus-carrying by an accredited laboratory.

3. In case of a disease outbreak, implement the current Biosecurity Plan.

4. It is recommended to grow more resistant species of salmonids $(87,91)$.

5. The losses can be limited by increase of temperature of water. It depends on IPNV strain and fish species (40).

6. Vaccination (of uterine herds) with appropriate vaccines should be done. At the present, several commercial vaccines are commercially available. The application is different: oral (107), by immersion (applied into $3 \mathrm{~g}$. fish body weight
(108), intramuscular (5 g) (109) or intraperitoneal injection (i.p. - 10-35 g) (108), by modulating Qtl regions of the genome (92). Aquaculture vaccination in Bulgaria is forbidden. (93). Some pharmaceutical company as IntervetInternational BV, Merck Animal Health, Microtek International, CDV, Pharmaq AS, Centrovet, Aqua Health Ltd, provide commercial vaccines.

\section{CONCLUSION}

Viral fish diseases are considered as the most important in Bulgaria. The IPN occurring increased since 2006.

The IPNV has a wide distribution in the most major salmonid-farming countries. In our geographical region it is present in a freshwater salmonid farms of our neighbours, as well as in all Balkan countries. It is present in the most countries with which we trade and import fertilizer eggs. Vertical transmission could be avoided by import from farms, free of IPNV or by laboratory test of eggs - before being hatched. Horizontal transmission can be done through a variety of organic vectors in which it can persist such as Black Sea shellfish, fish eating birds, wild salmonid, other wild and cultured fish populations, and mechanical vectors such as facilities, people in contact with infected fish, etc.

Field diagnosis is difficult since the clinical signs are nonspecific and a point of reference can be only age, body darkening pigmentation, and uncharacteristic swimming behaviour. Accurate and reliable laboratory methods are available. The gold standard is virus isolation in specific cell cultures and subsequent identification by serological techniques.

In recent years, molecular methods have become more sensitive and specific. RT PCR and RTqPCR have become methods of rapid routine diagnosis, but a major drawback is demonstrating the existence of a viral antigen without clarifying whether virus is alive and is it possible to develop. Therefore, the importance is sampling with great precision from predilection tissue, stored and transported according to accepted procedures.

Knowledge of the molecular features of the IPN virus, an interaction: "IPNV-host", "IPNV-fish cultured population", "IPNV-wild fish population" and "IPNV-other fish pathogens", assumes a deep understanding of the nature of IPNV and its behavior. There is not enough data of the epizootiological cycle but it is clear that the economic impact of IPN 
is high. It causes devastating losses of each affected farm. Good laboratories, veterinary and farming practices as well as legislative and executive authorities need up-to-date information for effective control and prevention.

$\begin{array}{ll}\text { ABBREVIATION } \\ \text { RNA } & \text { ribonucleic acid } \\ \text { DNA } & \text { deoxyribonucleic acid } \\ \text { IPN } & \text { infectious pancreatic necrosis } \\ \text { IPNV } & \text { infectious pancreatic necrosis } \\ \text { virus } & \\ \text { VHS } & \text { viral hemorrhagic septicemia } \\ \text { IHN } & \text { infectious hematopoietic } \\ \text { necrosis } & \text { infectious salmon anemia } \\ \text { ISA } & \text { cell culture } \\ \text { CC } & \text { epithelioma } \\ \text { EPC } & \text { papulosum } \\ \text { cyprinid cell line } \\ \text { BF2 } & \text { bluegill fry 2 cell line } \\ \text { CHSE-214 } & \text { chinook salmon cell line } \\ \text { RTG2 } & \text { rainbow trout gonad tissue cell } \\ \text { culture } & \\ \text { FHM } & \text { fathead minnow cell line } \\ \text { CPE } & \text { cythopatic effect } \\ \text { PCR } & \text { polymerase chain reaction } \\ \text { RT PCR } & \text { reverce } \\ \text { polymerase chain reaction } & \text { transcriptase } \\ \text { RTqPCR } & \text { quantitive reverce transcriptase } \\ \text { polymerase chain reaction } \\ \text { ELISA } & \text { enzyme linked immunosorbent } \\ \text { assay } & \text { indirect immunofluorescence } \\ \text { IFAT } & \\ \text { test } & \text { ultraviolet light } \\ \text { UV } & \end{array}$

\section{REFERENCES}

1. Annual agricultural report on the state and development of agriculture in the Republic of Bulgaria, Ministry of Agriculture, Food and Forestry, Bulgaria, 2017 г., http://www.mzh.government.bg/media/filer_ public/2018/01/24/agraren-doklad-2017.pdf

2. National report on the state of the environment in the Republic of Bulgaria. Ministry of Environment and water, Bulgaria, 2016, http://eea.government.bg/bg/soer/2016/water /index

3. Chikova, V., Dissemination of the viral and bacterial infections in aquaculture and analysis of epizootic situation in Bulgaria. Bulgarian Journal of Agriculture Science, Vol.3, pp. 52-62, 2014.

4. Lvov, D. K., Shchelkanov, M. Yu., Alkhovsky, S. V., Deryabin, P. G., Zoonotic viruses of Northern Eurasia. D.I.Ivanovski Institute of Virology, $1^{\text {st }}$ Edition, Elsevier, 2015.
5. De Aguar Pinheiro, A. C., Development of new molecular methods for the diagnosis and the study of viral diseases of fish. $P h D$ thesis, Universita di Bologna, 2007.

6. Rimstad, E., Infectious pancreatic necrosis Overview, Invasive Species Compendium, Norwegian School of Vet Sc, CABI, 2018.

7. Reno, P. W., Infectious pancreatic necrosis and associated aquatic birnaviruses. Fish diseases and disorders, Volume 3, Viral, bacterial and fungal infections. 1-55, 1999.

8. Vestergård-Jørgensen, P, Bregnballe, F., Infectious pancreatic necrosis in rainbow trout (Salmo gairdneri) in Denmark. Nordisk Veterinaermedicin. 21:142-148, 1969.

9. Besse, P., de Kinkelin, P., Sur l'existence en France de la nécrose pancréatique de la truite arc en ciel (Salmo gairdneri), Bulletin de l'Académie Vétérinaire, 38:185-190, 1965.

10. Schlotfeldt, H. J., Leiss, B., Frost, J.W., Erst isoleirung und identifizierung des virus der infektiosen pancreasnekrosl (IPN) der salmoniden in der Bundesrepublik Deutschland. Berliner und Munchener Tierärtzliche $\quad$ Wochenschrift, $\quad$ 88:109111,1975.

11. Ghittino, P., Malattie esotoche dei pesci che minacciano troticultura e carpicultura italiane. Rivista Italiana di Piscicoltura e Ittiopatologia, 7:53-62, 1972.

12. Hastein, T., Krogsrud, J., Infectious pancreatic necrosis. First isolation of virus from fish in Norway. Acta Veterinaria Scandinavica, 17(1):109-111, 1976.

13.Ljungberg, O., Vestergård-Jørgensen, P. E., Infectious Pancreatic Necrosis (IPN) of Salmonids in Swedish Fish Farms. European Inland Fisheries Advisory Committee, Technical Paper 17, supplement 2. Rome: FAO, 1973.

14. Ball, H. J., Munro, A. L. S., Ellis, A., Elson KGR., Hodgkiss, W., McFarlane, I. S., Infectious pancreatic necrosis in rainbow trout in Scotland. Nature, 234(No. 5329):417-418, 1971.

15. M'Gonigle, R. H., Acute catarrhal enteritis of salmonid fingerlings. Transactions of the American Fisheries Society, 70:297-302, 1941.

16. Sano, T., Studies on viral diseases of Japanese fishes I. Infectious pancreatic necrosis of rainbow trout: first isolation from epizootics in Japan. Bulletin of the Japanese Society of Scientific Fisheries, 37:495-498, 1971.

17.Jiang, Y., Xu, B., Li, W., Li, Z., Hu, Q, Isolation and identification of infectious pancreatic necrosis virus (IPNV) from imported rainbow trout (Salmo gairdneri) in 
PR China. Acta Hydrobiologia Sinica, 13:353-358, 1989.

18. Candan, A., First report on the diagnosis of infectious pancreatic necrosis (IPN) based on reverse transcription polymerase chain reaction (RT-PCR) in Turkey. Bulletin of the European Association of Fish Pathologists, 22(1):45-48, 2002.

19. Crane, M. St. J., Hardy-Smith, P., Williams, L. M., Hyatt, A. D., Eaton, L. M., Gould, A., Handlinger, J., Kattenbelt, J., Gudkovs, N., First isolation of an aquatic birnavirus from farmed and wild fish species in Australia. Diseases of Aquatic Organisms, 43(1):1-14, 2000.

20.Tisdal, D. J., Phipps, J. C., Isolation and characterisation of a marine birnavirus from returning Quinnat salmon (Oncorhynchus tshawitscha) in the South Island of New Zealand. New Zealand Veterinary Journal, 35(12):217-218, 1987.

21.Hedrick, R. P., Fryer, J. L., Chen, S. N., Kou, G. H., Characteristics of four birnaviruses isolated from fish in Taiwan. Fish Pathology, 18(2):91-97, 1983.

22.Hah, Y. C., Hang, S. W., Kim, M. H., Fryer, J. L., Winton, J. R., Isolation of infectious pancreatic necrosis virus from goldfish (Carassius auratus) and chum salmon (Oncorhynchus keta) in Korea. Korean Journal of Microbiology, 22:85-90, 1984.

23. Wattanavijarn, W., Torchy, C., Tangtronpiros, J., Kinkelin, P. de., Isolation of a birnavirus belonging to $\mathrm{Sp}$ serotype, from South East Asia fishes. Bulletin of the European Association of Fish Pathologists, 8(5):106-108, 1988.

24. Yasutake, W. T., Parisot, T. J., Klontz, G. W., Virus diseases of the Salmonidae in the western United States. II. Aspects of pathogenesis. Annals of the New York Academy of Sciences, 165:520-530, 1965.

25. Universal Virus Database of the International Committee on the Taxonomy of Viruses, ICTV, 2018.

26. Da Costa, B., Soignier S., Chevalier, C., Delmas., Henry, S., Thory, C., Huet, J. C., Delmas, B., Blotched snakehead virus is a new aquatic birnavirus that is slightly more related to Avibirnavirus than to Aquabirnavirus. Journal of Virology, 77(1):719-25, 2003.

27.Fenner, F., Fenner's Veterinary Virology. $5^{\text {th }}$ Edition, Elsevier, 2017.

28.Hill, B., Way, K., Serological classification of infectious pancreatic necrosis (IPN) virus and other aquatic birnaviruses. Annual Review of Fish Diseases, 5:55-77, 1995.

29.Dobos, P., The molecular biology of infectious pancreatic necrosis virus (IPNV).
Annual Review of Fish Diseases, 5:25-54, 1995.

30. Olesen, N.Y.,, Jorgensen, V., Bloch, B., Mellergaard, S., Isolation of an IPN-like virus belonging to the serogroup II of the aquatic birnaviruses from dab, Limanda limanda L. Journal of Fish Diseases, 11(5):449-451, 1988.

31. Nobiron, N., Galloux, M., Henry, S., Torhy, C., Boudinot, P., Lejal, N., Da Costa, B., Delmas, B., Genome and polypeptides characterization of Tellina virus 1 reveals a fifth genetic cluster in the Birnaviridae family. Virology 371(2):350-361, 2008.

32. Melby, H. P., Caswell-Reno, P., Falk, K., Antigenic analysis of Norwegian aquatic birnavirus isolates using monoclonal antibodies - with special reference to fish species, age and health status. Journal of Fish Diseases, 17(1):85-91, 1994.

33. Magyar, G., Dobos, P., Evidence for the detection of the infectious pancreatic necrosis virus polyprotein and the $17-\mathrm{kDa}$ polypeptide in infected cells and of the NS protease in purified virus. Virology, 204:580-589, 1994.

34. Delmas B., Mundt, E., Vakharia, V. N., 'Family Birnaviridae', in King, A. M. Q., Adams, M. J., Carstens, E. B., Lefkowitz, E. J., (eds.), Virus Taxonomy: Classification and Nomenclature of Viruses. Ninth Report of the International Committee on Taxonomy of Viruses. San Diego, CA, Elsevier Academic Press, 499507, 2012.

35. Duncan, R., Mason C. L., Nagy, E., Leong, J. A., Dobos, P., Sequence analysis of infectious pancreatic necrosis virus genome segment $B$ and its encoded VP1 protein: a putative RNAdependent RNA polymerase lacking the GlyAsp-Asp motif. Virology, 181:541-552, 1991.

36. Wood, E., Snieszko, S. F., Yasutake, W. T., Infectious pancreatic necrosis in brood trout. American Medical Association Archives of Pathology, 60:26-28, 1955.

37. Wolf, K., Fish viruses and fish viral diseases, Cornell University Press, xii + 476 pp, 1988.

38. Cutrin, J. M., Olveira, J. G., Barja, J. L., Dopazo, C. P., Diversity of Infectious pancreatic necrosis virus strains isolated from fish, shellfish, and other reservoirs in Northwestern Spain. Appl. and Environmental Microbiology, pp 839-843, 2000.

39. Souter, B. W., Dwilow, A. G., Knight, K., Yamamoto, T., Infectious Pancreatic Necrosis Virus in Adult Arctic Char, Salvelinus alpinus (L.), in Rivers in the Mackenzie Delta Region. Canadian Technical Report of Fisheries and Aquatic Sciences No 1441, 2. Toronto, Canada: Fisheries Research Board of Canada, 11 pp, 1986. 
40.Dorson, M., Torchy, C., Experimental transmission of infectious pancreatic necrosis virus via the sexual products. [Spermatozoa]. Fish and shellfish pathology, Proceedings of the European Association of Fish Pathologists, Plymouth, 251-260, 1985.

41. Mortensen, S. H., Evensen, O., Rodset, O. M., Hjeltnes, B. K., The relevance of infectious pancreatic necrosis (IPNV) in farmed Norwegian turbot (Scophthalmus maximus). Aquaculture, 115:243-252, 1993.

42. Wolf, K., Quimby, M. B., Bradford, A. D., Egg-associated transmission of IPN virus of trouts. Virology, 21:317-321, 1968.

43. Sonstegard, R. A., McDermott, L. A., Sonstegard, K. S., Isolation of infectious pancreatic necrosis virus from white suckers (Catastomus commersoni). Nature, 236(No.5343):174-175, 1972.

44. Ronneseth, A., Pettersen, E. F., Wergeland, H. I., Neutrophils and B-cells in blood and head kidney of Atlantic salmon (Salmo salar L.) challenged with infectious pancreatic necrosis virus (IPNV). Fish \& Shellfish Immunology, 20, 610-620, 2006.

45.Taksdal, T., Dannevig, B. H., Rimstad, E., Detection of infectious pancreatic necrosis (IPN)-virus in experimentally infected Atlantic salmon parr by RT-PCR and cell culture isolation. Bulletin of the European Association of Fish Pathologists, 21(5):214219, 2001.

46. Bowden, T. J., Lockhart, K., Smail, D. A., Ellis, A. E., Experimental challenge of postsmolts with IPNV: mortalities do not depend on population density . Journal of Fish Diseases, 26:309-312, 2003.

47.McAllister, P. E., Owens, W. J., Ruppenthal, T. M., Detection of infectious pancreatic necrosis virus in pelleted cell and particulate components from ovarian fluid of brook trout Salvelinus fontinalis. Diseases of Aquatic Organisms, 2(3):235-237, 1987.

48. Munanga'ndu, M. H., Santi, N., Frederiksen, B. N., Lokling, K. E., Evensen, O., A systematic approach towards optimizing a cohabitation challenge model for infectious pancreatic necrosis virus in Atlantic salmon (Salmo salar L.). PLoS ONE, 11(2), 2016.

49. Castric, J., Baudin-Laurencin, F., Coustans, M. F., Auffret, M., Isolation of infectious pancreatic necrosis virus, $\mathrm{Ab}$ serotype, from an epizootic in farmed turbot, Scophthalmus maximus. Aquaculture, 67(1/2):117-126, 1987.

50.Mortensen, S. H., Hjeltnes, B., Rdseth, O., Krogsrud, J. K., Christie, K. E., Infectious pancreatic necrosis virus, serotype N1, isolated from Norwegian halibut (Hippoglossus hippoglossus), turbot (Scopthalmus maximus) and scallops
(Pecten maximus). Bulletin of the European Association of Fish Pathologists, 10(2):4243, 1990.

51. Rodger, H. D., Frerichs, G. N., Clinical infectious pancreatic necrosis virus infection in farmed halibut in the United Kingdom. Veterinary Record, 140(15):401-402, 1997.

52. Evensen, O., Rimstad, E., Immunohistochemical identification of infectious pancreatic necrosis virus in paraffin-embedded tissues of Atlantic salmon (Salmo salar). Journal of Veterinary Diagnostic Investigation, 2(4):288-293, 1997.

53. McAllister, P. E., Owens, W. J., Infectious pancreatic necrosis virus: protocol for a standard challenge to brook trout. Transactions of the American Fisheries Society, 115(3):466-470, 1986.

54. Nakajima, K., Maeno, Y., Arimoto, M., Inouye, K., Sorimachi, M., Viral deformity of yellowtail fingerlings. Gyobyo Kenkyu = Fish Pathology, 28(3):125-129, 1993.

55.Jung, S. J., Kitamura, S. I., Kawai., K, Suzuki, S., Isolation of different types of birnavirus from ayu Plecoglossus altivelis and amago salmon Oncorhynchus rhodurus cultured in the same geographic area. Dis Aquat Org 38: 87-91, 1999.

56. Bootland, L. M., Dobos, P., Stevenson, R. M. W., The IPNV carrier state and demonstration of vertical transmission in experimentally infected brook trout. Dis. Aquat. Org. 10:13-21, 1991.

57. McKnight, I. J., Roberts, R. J., The pathology of infectious pancreatic necrosis. I. The sequential histopathology of the naturally occurring condition. British Veterinary Journal, 132(1):76-85, 1976.

58.Rud, Y., Buchatsky L., Detection of infectious pancreatic necrosis in the Western Ukraine. AQUA-2012, World Aquaculture Society Meeting, Prague, 2012.

59. Kim, H. J., Cho, J., Hwang, H., Oh, M., Nishizawa, T., Establishment and Characterization of the Epithelioma Papulosum Cyprini (EPC) Cell Line Persistently Infected with Infectious Pancreatic Necrosis Virus (IPNV), an Aquabirnavirus. The Journal of Microbiology, 50(5):821-826, 2012.

60. Gamil, A., Evensen, O., Mutoloki, S., Infectious Profiles of Selected Aquabirnavirus Isolated in CHSE cells. PLoS ONE, 10(8), 2015.

61. OIE, Manual of diagnostic tests for aquatic animals (MDTAA), 2006, http://www.oie.int/

62. Rodrigues Saint-Jean, S., Borrego, J. J., Perez-Prieto, S. I., Comparative evaluation of five serological methods and RT-PCR 
assay for the detection of IPNV in fish. Journal of Virological Methods, 97(1/2):2331, 2001.

63.McAllister, P., Schill, W. B., Owens, W. B., Hodge, D. L., Infectious pancreatic necrosis virus: a comparison of methods used to detect and identify virus in fluids and tissues of fish. In: Proceedings of the Second International Symposium on Viruses of Lower Vertebrates. Corvallis, Oregon, USA: Oregon State University Press, 191-202, 1991.

64. McAllister, P., Bebak, J., Infectious pancreatic necrosis virus in the environment: relationship to effluent from aquaculture facilities. Journal of Fish Diseases, 20(3):201-2017, 1997.

65.Lorenzen, E., Carstensen, B., Olesen, N. J., Inter-laboratory comparison of cell lines for susceptibility to three viruses: VHSV, IHNV and IPNV. Dis Aquat Organ, 37(2):81-88, 1999.

66. Rodrigues Saint-Jean, S., Borrego, J., PerezPrieto, S., Infectious pancreatic necrosis: Biology, Pathogenesis and diagnostic methods. Advances in virus research, Vol.62, 2003.

67. Espinoza, J., Kuznar, J., Rapid simultaneous detection and quantitation of infectious pancreatic necrosis virus (IPNV). Journal of Virological Methods, 105(1):81-85, 2002.

68. La Patra, S., Roberti, K., Rohovec, J., Fryer, J., Flurescent antibody test for the rapid diagnostic of infectious hematopoetic necrosis. J. of Aquatic Animal Health, 1(1):29-36, 1989.

69. Milne, S. A., Galachacher, S., Cash, P., Porter, A. J. R., A reliable RT PCR-ELISA method for the detection of infectious pancreatic necrosis virus (IPNV) in farmed rainbow trout. J. Virol. Meth., 132, 92-96, 2006.

70. Rimstad, E., Hornes, E., Olsvik, O., Hyllseth, B., Identification of a double-stranded RNA virus by using polymerase chain reaction and magnetic separation of the synthesized segments. Journal of Clinical Microbiology, 28:2275-2278, 1990.

71. Shankar, K.; Yamamoto, T., Epitope analysis of IPN virus isolates from feral and hatchery salmonid fishes by neutralizing monoclonal antibodies. Current Science, 67:95-98, 1994.

72. Blake, S., Schill, W., McAllister, P., Nicholson, B., Detection and identification of aquatic birnaviruses by PCR assay. Journal of Clinical Microbiology, 33(4):835-9, 1995.

73. Williams, K., Blake, S., Sweeney, A., Singer, J., Nicholson, B. L., Multiples reverse transcriptase PCR assay for simultaneous detection of three fish viruses. J. Clin. Microbiol., 37: 4139-4141, 1999.

74. Taksdal, T., Dannevig, B. H., Rimstad, E., Detection of infectious pancreatic necrosis (IPN)-virus in experimentally infected
Atlantic salmon parr by RT-PCR and cell culture isolation. Bulletin of the European Association of Fish Pathologists, 21(5):214219, 2001.

75. Alonso, M. C., Cano, I., Castro, D., PerezPrieto, S. I., Borrego, J. J., Development of an in situ hybridisation procedure for the detection of sole aquabirnavirus in infected fish cell cultures. Journal of Virological Methods, 116(2):133-138, 2004.

76. Heid, C. A., Stevens, J., Livak, K. J., Williams, P. M., Real time quantitive PCR, Genome research, 6(10):986-94, 1996.

77. Barlic-Maganja, D., Strancar, M., Hostnik, P., Jencic, V., Grom, J., Comparison of the efficiency and sensitivity of virus isolation and molecular methods for routine diagnosis of infectious haematopoietic necrosis virus and infectious pancreatic necrosis virus. $J$ Fish Dis 25: 73-80, 2002.

78. Shivappa, R. B., Song, H., Yao, K., AasEng, A., Evensen, O., Vakharia, V. N., Molecular characterization of $\mathrm{Sp}$ serotype strains of infectious pancreatic necrosis virus exhibiting differences in virulence. Diseases of Aquatic Organisms, 61:23-32, 2004.

79. Rexhepi, A., Scheinert, P., Berxholi, K., Hamidi, A., Sherifi, K., Occurrence of infectious pancreatic necrosis (IPNV) in farmed rainbow trout (Onchorhynchus Mykiss) in Kosovo. Veterinaria, 58, 47-53, 2009.

80. Ahmadi, N., Ahmadi, O., Akhlaghi, M., Hosseini, A., Tissue distribution of IPNV serotype $\mathrm{Sp}$ in naturally infected cultured rainbow trout, Onchorhynchus Mykiss (Wallbaum): an immunochistochemical and nested-PCR study. J of Fish Diseases, 36(7), 2013.

81.Dhar, A.K., Roux, M.R., Klimpel, K.R., Detection and quantification of infectious hematopoietic and haematopoietic necrosis virus (IHHNV) and white spot virus (WSV) of shrimp by real-time quantitativePCRusingSYBR Green chemistry. J. Clin. Microbiol. 39, 2835-2845, 2001.

82. Bowers, R., Lapatra, S., Arun, D., Detection and quantitation of infectious pancreatic necrosis virus by real-time reverse transcriptase-polymerase chain reaction using lethal and non-lethal tissue sampling. Journal of virological methods, 147:226-234, 2008

83. Orpetveit, I., Mikalsen, A., Sindre, H., Evensen, O., Dannevig, B., Midtlyng, P., Detection of Infectious pancreatic necrosis virus in subclinically infected Atlantic salmon by virus isolation in cell culture or real-time reverse transcription polymerase chain reaction: influence of sample preservation and storage. Journal of Vet Diagn Invest, 22:886$895,2010$. 
84. Aquatic animal diseases significant to Australia: Identification field guide. Australian Government, $4^{\text {th }}$ Edition, 2012.

85.Anon., IPN, http://library.enaca.org/

86.Kotob, M., Menanteau-Ledouble, S., Kumar, G., Abdelzaher, M., El-Matbouli, M., The impact of co-infections on fish: a review. Veterinary Research, 47-98, 2016.

87. Decision 1554/2015/EC, laying down rules for the application of Directive 2006/88/EC as regards requirements for surveillance and diagnostic methods, https://eurlex.europa.eu/legalcontent/EN/TXT/?uri=uriserv\%3AOJ.L_.20 15.247.01.0001.01.ENG

88. Zhu, L., Wang, X., Wang, K., Yang, Q., He, J., Geng, Y., Quyang, P., Huang, X., Outbreak of infectious pancreatic necrosis (IPNV) in farmed rainbow trout in China. Acta Trop., 170:63-69, 2017.

89. McAllister, P. E., Newman, M. W., Sauber, J. H., Owens, W. J., Isolation of infectious pancreatic necrosis virus (serotype $\mathrm{Ab}$ ) from diverse species of estuarine fish. Helgoländer Meeresuntersuchungen, 37(1/4):317-328, 1984.

90. Wallace, I. S., Gregory, A., Munro, E. S., Bain, N., Raynard, R. S., Infectious pancreatic necrosis virus isolated from hake, Merluccius merluccius, from Scotland. Bulletin of European Fish Pathologists, 25(2):86, 2005.

91. National Surveillance Program of Bulgaria, 2016 - 2018 г - Appendix 23,

92. Houston, R., Davey, J., Bishop, S., Lowe, N., Mota-Velasko, J., Hamilton, A., Guy, D., Tinch, A., Thomson, M., Blaxter, M., Gharbi, K., Bron, J., Taggart, J., Characterisation of QTL-linked and genome-wide restriction siteassociated DNA (RAD) markers in farmed Atlantic salmon. Genomics, 13:244, 2012.

93. Directive 88/2006/EC.

94. Ortega, C., Montes de Oca R., Groman, D., Yason C, Nicholson B., Blake S., Case report: viral infectious pancreatic necrosis in farmed rainbowtrout from Mexico. Journal of Aquatic Animal Health 14:305-310, 2002.

95. McAllister, P. E., Reyes, X. Infectious pancreatic necrosis virus: Isolation from rainbow trout Salmo gairdneri Richardson, imported into Chile. J Fish Dis, 7:319-22, 1984.

96. Ortega, C., Montes de Oca R., Groman D., Yason C., Nicholson B., Blake S. Case report: viral infectious pancreatic necrosis in farmed rainbowtrout from Mexico. Journal of Aquatic Animal Health 14:305-310, 2002.

97. MacDonald, R. D., Gower, D. A., Genomic and phenotypic divergence among three serotypes of aquatic birnaviruses (infectious pancreatic necrosis virus). Virology 114:187195, 1981.

98. Ariel, E., Olesen, N. J. Finfish in aquaculture and their diseases: A retrospective view of the European Community. Bull. Eur. Assoc. Fish Pathol. 22:72-85, 2002.

99. Molloy S., Experimental transmission of infectious pancreatic necrosis virus from the blue mussel, Mytilus edulis to cohabitating Atlantic salmon (Salmo salar) smolts. Appl Environ Micropbiol, 79(19):5882-90, 2013.

100. Mortensen, S. H., E. Bachere, G. Le Gall, Mialhe E., Persistence of infectious pancreatic necrosis virus (IPNV) in scallops Pecten maximus, Dis. Aquat. Org. 12:221-227, 1992.

101. Swanson R. N., Carlisle J. C., Gillespie J. H., Pathogenesis of infectious pancreatic necrosis virus infection in brook trout, Salvelinus fontinalis (Mitchill), following intraperitoneal injection, Journal of Fish Dis, November, Vol.5, Iss.6, 1982.

102. Smail, D. A., McFarlane, L. A., Bruno, D. W., McVicar, A. H. The pathology of an IPN-Sp sub-type (Sh) in farmed Atlantic salmon, Salmo salar L., post-smolts in the Shetland Isles, Scotland. J. Fish Dis. 18:631-638, 1995.

103. Wolf, K., Quimby, M. C., Bradford, A. D. Egg-associated transmission of IPNV of trouts. Virology 21:317-321, 1963.

104. Wolf K; Bullock GC; Dunbar CE; Quimby MC, 1969. Comparison Studies of IPN Viruses. Washington DC, USA: Division of Fishery Research, Bureau of Sport Fisheries and Wildlife Resource Publication No 77, 139141.

105. Frantsi, C., Savan, M., Infectious pancreatic necrosis virus: comparative frequencies of isolation from feces and organs of brook trout (Salvelinus fontinalis). Journal of the Fisheries Research Board of Canada, 28(No.7):1064-1065, 1971.

106. Register of aquaculture farms in Bulgaria, BFSA, 2019.

107. de las Heras, A. I., Rodriguez Saint-Jean, S., Perez-Prieto, S. I. Immunogenic and protective effects of an oral DNA vaccine against infectious pancreatic necrosis virus in fish. Fish \& shellfish immunology 28, 562-570, 2010.

108. Bravo, S., Midtlyng, P. J., The use of fish vaccines in the Chilean salmon industry 19992003. Aquaculture, 270:36-42, 2007.

109. Xu, L., Zhao, J., Liu, M., Ren, G., Jian, F., Yin, J., Feng, J., Liu, H., Lu, T., Bivalent DNA vaccine induce significant immune responses against infectious hematopoetic necrosis virus and infectious pancreatic necrosis virus in rainbow trout. Scientific Reports, 7:5700, 2017. 